\title{
Building Trust in Inter-Korean Relations
}

A Role for Renewable Energy?

Dean J. Ouellette*

(Kyungnam University)

〈CONTENTS〉

I . Introduction

II . Trust and Trust Building

III. "The Trust Building Process on the Korean Peninsula": An Effective Approach?

IV . North Korea: Citizens' Hardships and the Regime's

Insecurities
1. Citizens' Hardships

2. The Regime's Insecurities

$\mathrm{V}$. Building Trust in Inter-Korean Relations: A Role for Renewable Energy?

VI. Conclusion

- Key words : inter-Korean relations, trust building, nongovernmental organizations, energy assistance

\section{【ABSTRACT】}

The Park Geun-hye administration in South Korea has made "trust building" the focal point of its North Korea policy, with emphasis on improving the lives of the average North Korean citizen. Bearing in mind the longstanding and deep-rooted political competition and structural divide between the two Koreas, how can South Korea realistically and viably begin to build trust with North Korea? This article provides a sociological definition of trust and trust building so as to prescribe how the trust-building process might best begin between the

\footnotetext{
*The author would like to thank the journal's anonymous reviewers for their constructive criticisms and comments on an earlier draft of this article.
}

The Korean Journal of International Studies, Vol. 11, No. 2 (December 2013), 327-353.

(c) 2013 The Korean Association of International Studies 
two Koreas. Considering the hardships of the North Korean people due to the chronic energy shortages, insecurities of the leadership in Pyongyang, and shortcomings of Seoul's "trust-building process," South Korea should look toward supporting nongovernmental engagement with North Korea, with a focus on renewable energy assistance as part of its initial and long-term future engagement strategy.

\section{I . Introduction}

The new Park Geun-hye government in South Korea has identified "trust building" as the focus of its North Korea policy. This is a challenging task considering the ideological divide, long history of mutually antagonistic political relations, and virtual absence of channels of communication between the two Koreas, political and otherwise. The freeze in inter-Korean relations during the last five years of the predecessor Lee Myung-bak administration in the South and Kim Jong Il/Kim Jong Un leadership in the North has not improved matters. In addition, the successor Kim Jong Un regime in the North has yet to firmly consolidate its power and is faced with overcoming the country's food and energy shortages among other domestic challenges, creating a situation where the regime is less likely to make major alterations to its policy lines for fear of jeopardizing its survival. Considering the past history and present circumstances, in what way can the Republic of Korea (ROK or South Korea) realistically begin to advance trust building with the Democratic People's Republic of Korea's (DPRK or North Korea)?

This article proceeds as follows. In the next section, I define the terms "trust" and "trust building" in order to identify the different dimensions of trust and how as a process it is built. Based on this, I determine that Seoul should more highly emphasize a "people-centered approach" in its trustbuilding process with North Korea. The third section briefly examines Seoul's "Trust Building Process on the Korean Peninsula" and assesses whether it is conducive to such approach and engagement targets. In the fourth section, I review the general situation of the average citizens in North Korea, highlighting their hardships due to the chronic food and energy 
shortages, and the current situation of the ruling regime in Pyongyang, analyzing its perceived vulnerabilities and direction with its policy line in order to identify potentially acceptable and practical areas where "trustbuilding" engagement through a people-centered approach could initially focus. Finally, the article provides a recommendation on what South Korea can do to get the trust-building process with North Korea in motion; specifically, I argue that Seoul should promote nongovernmental engagement that focuses on renewable energy assistance to North Korea.

\section{II . Trust and Trust Building}

To determine how the two Koreas realistically and viably can begin to build trust at this juncture in time requires that we first define the terms "trust" and "trust building."

Trust is a social construct. It is treated differently by scholars of different fields. From an international relations' perspective, one might define trust as "an attitude involving a willingness to place the fate of one's interests in the control of others," and that trusting relationships are "behavioral manifestation of trust." ${ }^{\prime \prime)}$ Sociologists might conceptualize trust as a mental process comprising the elements of expectation, interpretation, and suspension. ${ }^{2)}$ Scholars of organizational and leadership studies may look at trust from a relational standpoint, defining it as "the willingness of a party to be vulnerable to the actions of another party based on the expectation that the other will perform a particular action important to the trustor, irrespective of the ability to monitor or control that other party." ${ }^{\prime 3)}$ But as Khodyakov points out, most social scientists do not view trust as a process: some regard trust as an independent variable, and therefore are primarily concerned with its benefits, while others view it as a dependent variable, looking at what directly impacts the development and maintenance of trust; however, some

1) Aaron M. Hoffmann, “A Conceptualization of Trust in International Relations," European Journal of International Relations 8-3 (2002), pp. 376-377.

2) Guido Mollering, "The Nature of Trust: From Georg Simmel to a Theory of Expectation, Interpretation and Suspension," Sociology 35-2 (2001), pp. 403-420.

3) Roger C. Mayer, James H. Davis, and F. David Schoorman, "An Integrative Model of Organizational Trust,” Academy of Management Review 20-3 (1995), pp. 709-734. 
sociologists argue against a "utilitarian usage of trust as a 'medium' or 'glue' that holds relationships and societies together" and instead emphasize "the dynamic foundation of trust, which involves the idea of trust building." In this case trust is seen as "a social practice and process because it involves the responsibility of both parties, commitment to the relationship, and the possibility of social change: to trust is to anticipate that the other party will exhibit benevolence supported by moral competence in the form of loyalty, generosity, and honesty."'4)

From this understanding, trust can be viewed as three-dimensional: thick interpersonal trust (strong ties), thin interpersonal trust (weak ties), and institutional trust. The first dimension, 'thick interpersonal trust', is best thought of as the 'basic trust' originating "in relationships with strong ties and depends on personalities of both the trustee and trustor, because it involves personal familiarity with the other person and strong emotional commitment to the relationship." The second dimension, "thin interpersonal trust', comes about when we interact with people whom we do not know well, "depends on the reputation of either a potential trustee or a trust intermediary," and therefore "represents reliance on weak ties and is based on the assumption that another person would reciprocate and comply with our expectations of his behavior, as well as with existing formal and ethical rules." Such trust is associated with high risks - such as lack of reciprocity and uncertainty - but it can provide greater benefits if reciprocated. The third dimension, institutional trust, is different from the former two dimensions in that the impersonal nature of institutions makes creation of such trust difficult. Nevertheless, in modern society it is often more important than the other forms of trust because of the resources institutions can usually provide to people so that they can achieve some of their goals. Thus, "trust in institutions depends on their perceived legitimacy, technical competence, and ability to perform assigned duties efficiently." ${ }^{5}$ )

In each dimension, the composition and levels are changeable over time and do not necessarily depend on each other. As trust is constantly changing, it should be treated "not as a variable with different levels of strength, but

4) Dmitry Khodyakov, "Trust as a Process: A Three-Dimensional Approach," Sociology 41-1 (2007), p. 125.

5) Quotes come from Ibid., pp. 120-124. 
rather as a process of its creation, development, and maintenance." $\left.{ }_{6}\right)$ Khodyakov goes one step further by viewing trust as a form of agency, ${ }^{7)}$ and thereby defines trust as "a process of constant imaginative anticipation of the reliability of the other party's actions based on (1) the reputation of the partner and the actors, (2) the elevation of current circumstances of action, (3) assumptions about the partner's actions, and (4) the belief in the honesty and morality of the other side." ${ }^{8)}$ As noted, such a definition reflects the idea of temporality and equally accounts for rational and non-calculative dimensions of human behavior.9

In addition, the power of generosity should not be underestimated when it comes to maintaining and building trust. According Klapwijk and Van Lange, generosity plays an underestimated role in helping to communicate and build trust in situations of negative 'noise' (i.e., when the "other" party every now and then behaves less cooperatively than intended). ${ }^{10)}$ Here I would suggest that generosity need not necessarily come in the form of tangible resources, but can include such intangibles as patience and understanding.

Considering the history of division of the peoples of the two Koreas and the

6) Ibid., p. 124.

7) Here Khodyakov relies on M. Emirbayer and A. Mische's definition of agency as "the temporally constructed engagement by actors of different structural environments ... which, through the interplay of habit, imagination, and judgment, both reproduces and transforms those structures in interactive response to the problems posed by changing historical situations." M. Emirbayer and A. Mische, "What is Agency?" American Journal of Sociology 103 (1998), pp. 962-1023, cited in ibid., pp. 125-126.

8) Dmitry Khodyakov, op. cit.

9) “The idea that trust is a process of an 'imaginative anticipation' goes beyond the rational choice perspective in that it stresses the notion of imagination, which implies that people cannot accurately predict the future, but are able to hypothesize about it. Human beings not only try to theoretically foresee their future, but they also try to step into the shoes of their partners and understand how they might act in a particular situation ... [giving] people a sense of predictability, or at least a sense of readiness for action. The above definition of trust also implies the existence of a non-calculable dimension of human behavior. People do not always view each other as being totally driven by the desire to maximize their own profits, as rational choice theorists would argue. People are not able to be completely rational in their decisions because they act in an environment characterized by everlasting uncertainty, fast changes, and risk. The unpredictability of the long-term future often encourages people to rely more on the honesty and morality of their partners than on their ability to act rationally." Ibid., pp. 126-127.

10) Anthon Klapwijk and Paul A. M. Van Lange, "Promoting Cooperation and Trust in 'Noisy' Situations: The Power of Generosity," Journal of Personality and Social Psychology 96-1 (January 2009), pp. 83-103. 
current antagonistic relationship between the leaderships of the North and South, it can be assumed that neither thick nor thin interpersonal trust exists at any level, and that the authorities on either side do not have any trust in the other's institutions.

\section{III. "Trust-Building Process on the Korean Peninsula": An Effective Approach?}

For South Korea, the new Park Geun-hye administration in Seoul has instituted a "Trust-Building Process on the Korean Peninsula," with its objectives being to develop inter-Korean relations, establish peace on the peninsula, and lay the groundwork for unification. Under her administration's policy, the two Koreas are to build trust gradually "through continued dialogue, a shared commitment to promises, and mutual endeavors of exchange and cooperation," with trust-building initiatives for normal interKorean ties to include continued efforts to address humanitarian issues, establishing channels of dialogue and ensuring delivery on agreements, expansion and development of mutual exchange and cooperation, and carrying-out of Vision Korea Projects. ${ }^{11)}$

Following the directions of this policy, President Park appears to be maintaining a principled approach to inter-Korean relations based on strict reciprocity. Her policy is underpinned by a strong commitment to security, carrying out agreements, shaping conditions to encourage North Korea to make the "right choices," all the while working on the basis of establishing domestic and international trust. ${ }^{12)}$ So far, the Park administration seems to be putting more emphasis on security posture and the nuclear issue, striving to build political and military trust first.

While it is too early in the president's term to evaluate the success of her approach, it is clear that Pyongyang has not embraced the new policy, calling

11) Ministry of Unification (MOU), "Trust-Building Process on the Korean Peninsula" (23 September 2013), available at <http://eng.unikorea.go.kr>.

12) Ibid.; see also "Full Text of Park's Inauguration Speech," Yonhap News (25 February 2013), available at <http://english.yonhapnews.co.kr/national/2013/02/25/95/ 0301000000AEN20130225001500315F.HTML>. 
it simply another version of "confrontation policy." This is not surprising. The North Korea regime does not emphasize "trust" as a condition of interKorean relations. Rather, the ideal that must be respected and implemented for inter-Korean relations to improve is 'uriminzokkiri' ('by our nation itself' $).{ }^{14)}$ For Pyongyang, this means that the conditions for improvement in inter-Korean relations should be the Korean people first and foremost, and Korean solidarity; under Kim Jong Un, North Korea appears to be holding fast to this ideal. ${ }^{15)}$

However, the fact that Seoul's policy puts some emphasis on improving the lives of ordinary North Koreans and on fostering social and cultural exchanges is encouraging. To build trust with the North Korean authorities and ordinary people, aid and assistance, and exchanges, will be important as a sign of Seoul's generosity and willingness to allow South Korean civil society to partake in the inter-Korean activities. Seoul will also have to take into account North Korea's sensitivities more broadly.

To date, the Park government has indicated its willingness to deliver humanitarian aid regardless of political and diplomatic developments, pledging from its inter-Korean cooperation fund USD 6.3 million to the United Nations' World Health Organization to be used toward repairing North Korean medical facilities, training healthcare workers, and providing essential medicines to those in need. ${ }^{16)}$ The administration has also promised to increase the number of South Korean civic groups allowed to provide various aid (i.e., medical supplies, baby formula, soup, vitamins, soy milk, etc.) to not only the vulnerable (i.e., newborns, young children, and pregnant

13) “Another Version of Confrontation Policy," Pyongyang Times (25 May 2013); "Sinister Intent," Pyongyang Times (1 June 2013).

14) For recent examples in the North Korean media, see "Cornerstone of Korean Reunification," Pyongyang Times (1 June 2013); "It's Time to Reset Relations," Pyongyang Times (8 June 2013); "Key to Peace and Reunification of Korea," Pyongyang Times (17 August 2013).

15) As a former high-level North Korean defector points out, Kim Jong Un's 2013 New Year speech called attention to the " $65^{\text {th }}$ Anniversary of the Founding of the DPRK" and " $60^{\text {th }}$ Anniversary of Victory in the Homeland Liberation War" as national holidays to be highlighted in the year, signaling his refusal of "trust" as the ideal for inter-Korea relations. Jin-sung Jang, "Kim Jong Un's New Year Speech: What It Really Means (Part 2 of 2)," NK News (3 January 2013), available at <http://www.nknews.org>.

16) “S. Korea to Give US\$6.3 Mln in Humanitarian Aid to N. Korea," Yonhap (2 September 2013), available at <http://english.yonhapnews.co.kr/northkorea/2013/09/02/ 0401000000AEN20130902005100315.html>. 
women) but all citizens in need of assistance. Addressing the humanitarian concerns separate from the political agenda is a positive step toward repairing the inter-Korean relationship.

But building trust will require South Korea to go further by promoting social exchanges more actively. If reconciliation and unification are goals of both Koreas, then trust needs to be built not only at the political but at the societal level as well. Ties of thin interpersonal trust conceivably can and need to be built between the two societies. The North Korean people themselves need opportunities to build these 'weak ties' with ordinary South Koreans that will help establish trust-building relationships necessary for reconciliation between the two Koreas, and to help them survive in a future North Korea that is more economic oriented.

Building trust involves willingness to take risks. For Seoul, this will require two things: increasing the material incentives to North Korea and empowering South Korean civil society to partake in the trust-building process. Specifically, beyond provision of humanitarian aid, Seoul also should begin to provide selective development assistance even before the North Korean nuclear issue is resolved. Such projects should also be administered by South Korean nongovernmental groups.

With the understanding that if trust is to be built between the two Koreas it will have to start at the dimension of 'thin interpersonal trust' and that such trust can best begin to be built at the societal level, this article proceeds with an examination of the current situation in North Korean society, looking particularly at the hardships people face due to the country's chronic energy crisis and the insecurities of the regime. In this way, areas where trustbuilding engagement can be identified - that is, engagement that has more immediate impact on improving the lives of ordinary North Korean citizens, thereby establishing ways to build trust with the North Korean citizenry; as well, engagement that may help the regime overcome some of the domestic challenges it faces, mitigating its insecurities and subsequently be engagement acceptable to the Kim regime and thus concomitantly work to establish weak bonds of trust between Seoul and Pyongyang. 


\section{North Korea: Citizens' Hardships and the Regime's Insecurities}

\section{Citizens' Hardships}

The CIA World Factbook estimates North Korea's population to be 24,720,407 (as of July 2013) - about half that of South Korea. ${ }^{17)}$ Hundreds of thousands of North Koreans died during the famine period of the mid1990s - a man-made tragedy due partly to the energy shortages exacerbated by natural disasters. But estimated figures suggest the number of deaths attributable to the deterioration in living conditions in North Korea in the ten years following the famine is as high as the number of deaths attributable to the famine itself. ${ }^{18)}$ Studies in population trends and quality of life in North Korea indicate that living conditions for the average North Korean continue to deteriorate. ${ }^{19)} \mathrm{UN}$ food agencies' assessments warn that North Korea's food shortage remains serious, with chronic under-nutrition also a major concern. ${ }^{20)}$

As well, North Korea's energy shortages continue to be a chronic problem, affecting citizens in many ways. For example, students and their parents are reportedly required to supply firewood for the heating of schools. Lack of energy for heating in cold winters means water pipes freeze, making it difficult for people to access fresh water. Hunger and cold are exacerbated in winter months for those without access to firewood or heating oil. ${ }^{21)}$ In the

17) Central Intelligence Agency (CIA), The World Factbook, online at <http://www.cia.gov/ library/publications/the-world-factbook> (accessed on 31 July 2013).

18) Recent counterfactual population projections put the number of lives lost during the famine to be in the range of 240,000 and 420,000 people. Thomas Spoorenberg and Daniel Schwekendiek, "Demographic Changes in North Korea: 1993-2008," Population and Development Review 38-1 (March 2012), pp. 154-155.

19) Ibid., p. 156; Soo Am Kim et al., The Quality of Life of North Korean: Current Status and Understanding (Seoul: KINU, December 2012).

20) World Food Programme, "Last Quarterly Monitoring and Evaluation Bulletin of Protracted Relief and Recovery Operation 200114 'Nutrition Support to Women and Children”" (7 August 2013), available at <http://www.wfp.org/node/3498/4564/488940>; "Special Report, FAO/WFP Crop and Food Security Assessment Mission to the Democratic People's Republic of Korea" (12 November 2012), available at <http://www.fao.org/docrep/016/al994e/al994e00.pdf>.

21) "North Korean Economy Suffers in the New Year: Power Shortages and Prices on the Rise,” NK Brief No. 11-01-26, Institute for Far Eastern Studies (26 January 2011), available at <http://ifes.kyungnam.ac.kr/eng/FRM/FRM_0101V.aspx?code=FRM1012_000408>. 
drive to generate much needed power, hydroelectric dams are being constructed; but reportedly the conditions in which the people sometime work are arcane, as dams are built and tunnels dug by hand. ${ }^{22)}$ As well, lack of fuel and electricity to power machinery and equipment means more labor is needed to complete farming and construction tasks. Under the circumstances, youth involvement in dangerous and laborious work seems to be increasing, as more than 3,000 shock brigades for economic construction are said to be solely comprised of young people, ${ }^{23)}$ including those involved in the largescale labor-consuming projects such as the Taegyedo tideland reclamation and Paektusan Songun Youth Power Station construction. ${ }^{24)}$ In these examples, lack of energy supplies looms as an aspect of the people's hardships.

If the prevailing situation with regard to the energy shortages continues, it can only work to further erode the little confidence citizens may have in North Korea's own institutions, putting further pressure on the regime.

22) "Knowledge Transfer and Training in a Difficult Climate-Cooperation with North Korea in the Areas of Climate Change and Green Development," Hanns Seidel Foundation, available at <http://www.hss.or.kr/A1250English.html> (accessed on 21 September 2012). This may even be the case for some of the hydroelectric plants being built under the framework of the "Clean Development Mechanism" (CDM) and projects registered with the Intergovernmental Panel on Climate Change (IPCC). For more on these CDM projects and North Korea, see ibid. North Korea has acknowledged its efforts in this direction. See "Carbon Trade Arouses Interest," Pyongyang Times (19 November 2011), p. 4.

23) "Korean Youths Devote Themselves to National Defense, Building of Thriving Nation," KCNA (26 August 2013).

24) "Youths at Forefront of Building Thriving Nation," Pyongyang Times (27 August 2011), p. 5. It should be noted that the emphasis on young people in economic construction is not necessarily new and not necessarily a response solely to the energy crisis. Back in 1975, Kim Il Sung placed great emphasis on the work of young people and their role in the socialist revolution by carrying out the then new "Three Revolutions" campaign. The motive was to urge people to recognize the leadership of his son, Kim Jong Il, at the time newly seen as the heir to Kim Il Sung, and to improve the slumping economy by putting more youth into industrial and agricultural production. For Kim Il Sung's speech to this effect, see "Let Us Promote the Building of Socialism by Vigorously Carrying Out the Three Revolutions: Speech at the Meeting of Active Industrial Workers, March 3, 1975," in Kim Il Sung Works, vol. 30 (January-December 1975) (Pyongyang: Foreign Languages Publishing House, 1987), pp. 83-118. 


\section{The Regime's Insecurities}

Under Kim Jong Il's leadership, North Korea was a garrison state practicing guerrilla-like policies, ${ }^{25)}$ perceiving the external environment to have remained hostile toward the DPRK, and the country's economic situation woeful. Kim Jong Il himself maintained that to guarantee North Korea's sovereignty and right to socialism, prevent the country from being dominated by other states, and build a prosperous and powerful country, North Korea must possess strong self-defensive military capabilities. ${ }^{26)}$ Historically, in times of hardship and increasing threats to the regime, North Korea has prioritized the military at the expense of its people and the civilian economy. This includes Kim Jong Il's shift to prioritize military affairs amidst the country's energy crisis, making the army the main force of North Korea's (socialist) revolution beginning in the mid-1990s with the advent of songun (military-first) politics. ${ }^{27)}$

Nevertheless, North Korea's conventional forces have been in slow decline. The Korean People's Army (KPA) is said to lack fuel for its equipment, with estimates suggesting it has only enough to support itself for one month in a wartime setting. ${ }^{28)}$ North Korea also recently reduced the minimum height of soldiers to 1.45 meters (4 feet, 9 inches) ) $^{29)}$-a legacy of chronic food shortage on the population, and thus the army's rank and file. Recent reports suggest that the desertion of enlisted soldiers in frontline units due to frequent

25) In the supposed words of Kim Jong Il in 2003, "As written in the poem, last year really can be said to be a year of guerrilla in which I led the Songun revolution in a guerrilla way. This year is also to be a year of guerrilla, a year of bold offensive, like the previous year." Kim Jong Il the Great Man (Pyongyang: Foreign Languages Publishing House, 2012), p. 230.

26) Jong Chol Ri, Songun Politics in Korea (Pyongyang: Foreign Languages Publishing House, 2012), p. 25.

27) North Korea's "military-first" or songun is a policy which prioritizes the Korean People's Army in the affairs of the state and the allocation of resources. Since its inception, the concept has been expanded, functioning simultaneously and in varying degrees in the political, economic, and ideological realms of governance of the state and society. For discussion, see Dae-Sook Suh, "Military First Politics of Kim Jong Il," Asian Perspective 26-3 (Fall 2002), pp. 145-167.

28) Peter Hayes and David F. von Hippel, "DPRK 'Collapse' Pathways: Implications for the Energy Sector and for Strategies Redevelopment/Support," NAPSNet Special Report (18 January 2011), available at <http://www.nautilus.org >.

29) "North Korea’s $\$ 850$ million Rocket Failure," CNN.com (13 April 2012). 
training and lack of food rations is a constant problem. ${ }^{30)}$

Such decline could not inspire the regime's confidence in the country's conventional forces for defense. Accordingly, North Korea has pursued development of ballistic missiles and nuclear deterrent capability, and continues to do so, further revealing the regime's intrinsic perception of external threat and insecurity. As the media statements and Kim Jong Un's praising of the army and military-first politics indicate, going forward, one can expect that the regime will continue to bolster the DPRK's "military muscle" by augmenting its asymmetric military (threat) capabilities and to prioritize the army. ${ }^{31)}$

However, the ongoing energy crisis has led to a continual decline in the North Korean economy and energy sector. For the leadership, any perceived external threats now must give way to the growing internal challenges and domestic changes. The regime cannot completely stop the flow of information coming from the outside into the DPRK, putting into question the false paradigms the North Korean government has propagated for decades, such as that of a poverty-stricken South Korea. Markets and money-the socalled "evils of capitalism" - are playing bigger roles in the daily lives of the people. ${ }^{32)}$ The institution of 'organizational life' in North Korea is on the decline, ${ }^{33)}$ with the sense of collective values and mindset diminishing, and

30) “Despite War Threats, N. Korean Border Units Hit by Growing AWOLs," Vantage Point 36-4 (April 2013), p. 60.

31) "Only the self-defensive military capabilities, not a word, can reliably protect the sovereignty and right to existence." "Military Capabilities Guarantee Sovereignty to Existence: Rodong Sinmun," KCNA (30 May 2012). In the words of the young leader: "Songun is our independence, dignity, and lifeblood." Kim Jong Un, "Let Us Brilliantly Accomplish the Revolutionary Cause of Juche, Holding Kim Jong Il in High Esteem as the Eternal General Secretary of Our Party-Talk to Senior Officials of the Central Committee of the Workers' Party of Korea, April 6, Juche 101 (2012)” (Pyongyang: Foreign Languages Publishing House, 2012), p. 12; "President Kim Il Sung ... clarified in his early years the iron truth that arms are the lifeline of a nation." Kim Jong Un, "Let Us March Forward Dynamically Towards Final Victory, Holding Higher the Banner of Songun-Speech Delivered at the Military Parade Held in Celebration of the Birth of the Generalissimo Kim Il Sung, April 15 Juche 101 (2012)" (Pyongyang: Foreign Languages Publishing House, 2012), p. 3.

32) Soo Am Kim et al., op. cit.; "The Double Lives of Ordinary North Koreans," New Focus International (5 March 2013), available at <http://newfocusintl.com/the-double-lives-ofordinary-north-koreans/> (accessed on 10 March 2013).

33) Andrei Lankov, "North Korea's 'Organizational Life' in Decline," Asia Times (22 May 2012); see also Soo Am Kim et al., op. cit. 
criticism of the government rising. ${ }^{34)}$ Privately, people hold the regime in low regard, with their assessments of the regime being highly negative. ${ }^{35}$

Prior to the high tensions and bellicose rhetoric following North Korea's third nuclear test in February 2013 and subsequent new level of UN Security Council sanctions against the DPRK, the Kim Jong Un leadership had sent out some encouraging signs. In the first half of 2012, the young Kim Jong Un seemed to have assumed a leadership style characterized by more openness and relaxation. Economic recovery and social stability appear to be major concerns. It was reported that Kim Jong Un ordered North Korean officials to change the economic system and learn more about market economies. Various laws dealing with opening (e.g., foreign investment, foreign investment banks, labor conditions, taxation) have been revised. More technocrats, middle-ranking executives, and specialists are being sent abroad for capacity building to obtain technical skills and expertise in fields including finance, economic development, trade, energy, railway works, international business law, among others. ${ }^{36}$ More foreign experts and educators are also being allowed into Pyongyang to deliver on-site training and lectures. ${ }^{37)}$

Yet the food and energy shortages are still chromic problems affecting the average citizen. If the regime is unable to ameliorate these shortages, it will

34) Byeong-no Kim, "Talbukja myeonjeobjosareul tonghae bon bukhansahoiui byeonhwa, 2008-2011" [Social Changes in North Korea, 2008-2011: Based on North Korean Refugees Survey], Hyeondaebukhanyeongu [North Korean Studies Review] 15-1 (April 2012), pp. 39-84. Interestingly, the study nevertheless concluded that the recent economic, cultural, and social changes have not produced a significant effect on the political conscience of North Korean citizens, as pride in the juche ideology has been maintained, along with support for the Kim regime, due to the low-level political consciousness of the citizens and effective propaganda of the regime.

35) For the refugee surveys that substantiate this claim, see Stephan Haggard and Marcus Noland, Witness to Transformation: Refugee Insights into North Korea (Washington, DC: Peterson Institute for International Economics, 2011).

36) Min Gi Kim, "Moves Toward Change Under the Kim Jong-Un Regime," Vantage Point 35-8 (August 2012), p. 24.

37) The Pyongyang University of Science and Technology - jointly run by the DPRK ministry of education and international foundation (The North-East Asia Foundation for Education and Culture, in Seoul) —alone plans to recruit 200 foreign faculty members from the US, Europe, and South Korea over the next ten years. Remarks by Dong-hoon Ko at the international conference on Capacity Building and Knowledge Sharing with North Korea: Past Successes and Future Prospects, Seoul, Korea, 12 June 2013. 
not be able to improve its economy or the livelihoods of the people as it has promised, and therefore will have to face rising discontentment in society. Likewise, the country's conventional forces are more crucial to its regime security than its nuclear weapons programs. But keeping the soldiers loyal to the regime also means providing them with heat and food to stay relatively warm and healthy. One can be guardedly optimistic that once Kim Jong Un has fully consolidated his power, his regime will move forward with measures to deal with these challenges, cautiously and slowly, assessing each move's threat potential to regime survivability. However, abandoning the ruling juche ("self-reliance") ideology and songun is an unlikely proposition. ${ }^{38)}$ The regime will probably stay the course for some time, unwilling to abandon its nuclear programs.

\section{Building Trust in Inter-Korean Relations: A Role for Renewable Energy?}

In light of the prevailing situation, what can be done to improve the interKorean relationship and nudge North Korea onto a better path to be able to deal with the domestic challenges it faces? What assistance could more immediately improve the quality of life for ordinary citizens? What projects can be undertaken that would be politically and legally acceptable from an international standpoint, could possibly gain acceptance from Pyongyang, and would also allow for meaningful people-to-people exchanges that can help advance the sharing of ideas and possibly begin the process of building the bonds of trust between people?

To build trust with North Korea, Seoul will need to place attractive incentives on the table, including energy assistance - a political 'hot potato' especially because of the nuclear issue. Currently, Pyongyang's provocative behavior, including its recent rocket launch in December 2012 and underground nuclear test in February 2013, and its newly adopted economic

38) Kim Jong Un, "Let Us Brilliantly Accomplish the Revolutionary Cause of Juche, Holding Kim Jong Il in High Esteem as the Eternal General Secretary of our Party: Talk to Senior Officials of the Central Committee of the Workers' Party of Korea, April 6, Juche 101 (2012)" (Pyongyang: Foreign Languages Publishing House, 2012). 
line ${ }^{39)}$ and law on consolidating the DPRK as a "nuclear weapons state for self-defense" ${ }^{40)}$ suggest the near intractability of the North Korean nuclear issue in the short-to-medium term. North Korea continues to assert its sovereign right to civilian nuclear programs for energy production ${ }^{41}$-as promised to them in the September 2005 joint statement made thorough the Six Party Talks process. More will need to be done at the political level by state actors - especially North Korea - to achieve a diplomatic breakthrough that will return all relevant parties to multilateral talks for meaningful negotiations on the nuclear issue.

In the meantime, provision of energy assistance through development cooperation and expanding related capacity building programs should be considered as part of a package of incentives and as a means to begin the trust-building between the two Koreas. As trust can be built through small steps and various relationships, so too should be the approach to energy assistance. In this light, Seoul should seek to address North Korea's energy shortages in some minor yet significant and innovative form that reinforces infrastructure for unification - that is, increased South Korean public engagement and improved quality of life for North Koreans.

To address this through a people-centered approach to the trust-building process, South Korean NGO reengagement with North Korea should be prioritized, and done through small-scale renewable development cooperation energy projects directed at improving conditions of vulnerable rural communities in the North. While not a long-term solution to North Korea's energy crisis, renewable energy cooperation and its provision is a suitable, innovative, and safer approach from which to start to ameliorate North Korea's energy shortages for the rural populations in the short-term while overcoming political complications related to providing energy to the DPRK. Several reasons make this proposal attractive.

39) "Our Party Line of Economic Construction and Nuclear Weapons Development Is Permanent," Rodong Sinmun (3 May 2013) (in Korean).

40) "Law on Consolidating Position of Nuclear Weapons State Adopted," KCNA (1 April 2013).

41) North Korea further rationalizes that countries like China, Iran, Pakistan, Russia, and others are involved in nuclear cooperation for the construction of atomic power plants, and that "more positive efforts will be needed to develop and use nuclear energy for meeting growing needs for energy." "Nuclear Energy Development Widely Sought," Pyongyang Times (19 November 2011), p. 7. 
First, as alluded to earlier, it is inconceivable that Seoul would consider any large-scale energy projects until significant mutual confidence is built between the governments of North and South Korea. Large-scale projects do have symbolic value but are politically risky, cost prohibitive, and could not meet the immediate basic energy needs of ordinary people.

A cooperative approach that embraces the principle of "starting small" and allows for civil society to get involved in the inter-Korean development cooperation projects would be more prudent. Development cooperation works when a recipient actively requests it to supplement its lacking internal capacity while simultaneously pursuing other measures to improve its capacity. In the realm of cooperation, South Korean NGO engagement with North Korea has had its successes and failures, ${ }^{42)}$ and was instrumental for past South Korean government's engagement policy. NGOs do have a significant role to play in the trust-building with North Korea, especially if they are focused on engaging people at the community level, establishing linkages, and promoting innovation. Such roles are essentially needed in order to coax North Korea toward economic reform and opening and gain the trust of the North Korean people. South Korean NGO engagement with North Korea also represents a significant first step toward people-to-people reconciliation, which is the foundation in which Korean unification must be built. ${ }^{43)}$ Granted, past South Korean NGO engagement, largely consisting of delivery of humanitarian aid, had mixed results; yet South Korean NGOs did place great emphasis on trust building, did engage in some development cooperation, yielding positive impact. During the years of previous administrations' 'Sunshine policy' a number of NGOs were actively engaged in cooperative rural agricultural projects in conjunction with general humanitarian aid efforts, making rural cooperation a practical means in which

42) For discussion, see Edward P. Reed, "From Charity to Partnership: South Korean NGO Engagement with North Korea," in Sung Chull Kim and David C. Kang (eds.), Engagement with North Korea: A Viable Alternative (Albany, NY: SUNY Press, 2009), pp. 199-223; Oknim Chung, "The Role of South Korean NGOs: The Political Context," in L. Gordon Flake and Scott Snyder (eds.), Paved with Good Intentions: The NGO Experience in North Korea (Westport, CN: Praeger, 2003), pp. 81-110; Keum-soon Lee, A Study of Civil Organization Aid to North Korea and South-North Cooperation (in Korean) (Seoul: KINU, 2004).

43) Edward P. Reed, op. cit., 2009, p. 218. 
to reengage. ${ }^{44)}$

Second, renewable energy cooperation would be consistent with North Korea's interests and policy direction. In its past interaction with the Korean Peninsula Energy Development Organization (KEDO), meetings with European Union, work with energy-related UN projects, and communication through private channels, North Korean energy experts and officials have stated their energy priorities and goals, which include development of renewable energy systems. ${ }^{45)}$ North Korea began to show even more interest in renewables back in 2011. ${ }^{46)}$ The incumbent Kim Jong Un regime continues to demonstrate significant interest in renewables, as evidenced by the Presidium of the Supreme People's Assembly's recently enacted new law on renewable energy. Reports suggest that North Korea is even establishing legal framework to support this law. ${ }^{47)}$ Renewables also mesh with the regime's emphasis on advancing the country's science and technology. Likewise, from the North Korean perspective, projects that promote self-contained, selfsustainable development are favored because in one sense they suit the 'selfreliant' style of development that the regime emphasizes.

Third, cooperation in renewables would allow for the effects of technology transfers to go beyond one-dimensional transfers or one-time energy deliveries, provide a localized alternative to the crumbling transmission and distribution network and infrastructure, and be a more publically acceptable and safer venue to engage the North, and more likely to avoid the drawbacks related to technology and funds diversion to the military and North Korea's nuclear programs. ${ }^{48}$

44) Oknim Chung, op. cit., pp. 81-110.

45) Peter Hayes et al., "Grid-locked," Bulletin of the Atomic Scientists 62-1 (January/February 2006).

46) "North Korea also Turning to Renewable Energy Sources," Asahi Shimbun (29 November 2011), available at <http://ajw.asahi.com/article/asia/korean_peninsula/ AJ201111290057>.

47) "Law on Renewable Energy Enacted in DPRK," KCNA (2 September 2013).

48) Sul-Ki Yi, Haw-Young Sin, and Eunnyeong Heo, "Selecting Sustainable Renewable Energy Source for Energy Assistance to North Korea," Renewable and Sustainable Energy Reviews 15 (2011), pp. 554-563; David von Hippel, Scott Bruce, and Peter Hayes, "Transforming the DPRK Through Energy Sector Development," 38 North, Special Report 11-3, Washington, D.C.: U.S.-Korea Institute at SAIS, Johns Hopkins University (4 March 2011), available at <http://www.38north.org>; Virginie Grzelczyk, "Uncovering North Korea's Energy Security Dilemma: Past Policies, Present Choices, Future 
Fourth, provision of renewables such as small wind turbines and solar panels for generating electricity and producing hot water in schools and hospitals could be more easily monitored -while it is hard to determine whether profits from ventures such as the Gaeseong Industrial Complex (GIC) are being diverted to the military, when devices like wind turbines and solar panels go missing from the public facilities they are intended for, the regime risks not only losing the trust being built with South Korean donors but more importantly the trust it must begin to rebuild with its own people in North Korean institutions.

Fifth, supporting NGO engagement in such cooperation would necessitate for people-to-people exchanges in programs designed, for example, to build the technology development capability of North Koreans via sharing of information and equipment training in capacity-building workshops. These could help form the building blocks for some type of sustained engagement, keeping the interaction on a technical level and avoiding the political.

Sixth, the international community, too, largely through international organizations and NGO involvement, has had some success in its engagement with North Korea in introducing new energy practices and renewable energy. For example, Swiss-sponsored organizations brought about 15 officials from the DPRK Ministry of Electric Power Industry and from provinces to Switzerland for capacity building training on how to rehabilitate small hydropower plants. This demonstrated to the North Koreans the potential of such plants to address North Korea's own persistent power shortages. The knowledge acquired by the participants was said to be instrumental in helping North Korea draft a new law on hydropower development and related principles, which was approved in November 2008. ${ }^{49)}$

As another example, World Vision International (WVI) played an important role in experimenting with solar power and biogas projects, providing solar powered generators to the school and clinic, and an alternative source of heating to the farming community of Dochi-ri, Yongtan County, North Hwanghae Province. The Dochi-ri project itself was thought to be the first of

Opportunities," Central European Journal of International and Security Studies (CEJISS) 61 (January 2012), pp. 132-154.

49) Swiss Agency for Development and Cooperation (SDC), "Catching Up on Capacity in DPR Korea-Partnership Results,” Asia Brief(January 2011), p. 2. 
its kind in the country to provide an organic fertilizer plant and solar energy. The community now enjoys "a holistic approach" in addressing issues of food security, basic community health care, the supply of clean water and renewable energy. The positive impact led the DPRK government to encourage other agencies working in North Korea to consider replicating the project elsewhere. The success of WVI's clean water project in Chilbong, North Hwanghae Province helped spur that community to work cooperatively with WVI technicians on construction of a biogas plant to solve the village's lack of energy for heating homes in the winter. Through its work on these and other projects, WVI was able to come to a better understanding with its DPRK counterparts of the meaning of genuine partnership. ${ }^{50)}$

A third example is the Nautilus Institute's spearheading of a sustainable wind power project in Unhari Village in North Korea. Rural areas have been using small-scale locally-made wind turbines for years so as to be able to generate electricity when the country's electricity grid - which is highly unreliable - is unelectrified and as an alternative to diesel-powered generators due to the high cost of fuel. The Nautilus Institute's wind power project included interaction with various officials, local technicians, and village operators, among others. Despite the fact that the system installed could only produce a limited amount of electricity, it was "very much appreciated by villagers, simply because it provided electricity when people wanted it." ${ }_{51}$

This sentiment was shared by the beneficiaries of the United Nations Development Program's small wind energy project in Hanchon, a district in Pyongwon county of South Pyongan Province. The UNDP has been involved in constructing small wind turbines in rural communities. The overall role of the project has been to promote and diffuse green technology in households and public buildings by improving quality standards, guidelines, and

50) "Renewable Energy in the DPRK," NCNK Newsletter 2-1 (13 January 2009); Victor W.C. Hsu, "Getting Acquainted with North Korea: A Journey of Gradual Discovery," 38 North, Washington, D.C.: U.S.-Korea Institute at SAIS, Johns Hopkins University (1 April 2010), available at <http://www.38north.org/?p=225>; Kevin Jenkins, "North Korea: Waiting and Working in the DPRK," World Vision International (12 September 2011) and "North Korea: The Old People Danced all Night," World Vision International (4 October 2011), available at <http://www.wvi.org>.

51) For a case study of the project, see Chris Greacean and Nautilus Team, "Rural Reelectrification in the DPRK," Asian Perspective 26-1 (Spring 2002), pp. 65-67. 
demonstrating best practices. Through this project, UNDP has reportedly achieved some measure of success in supporting rural populations to improve their lives in concrete ways. ${ }^{52}$

Taking these cases into consideration, Seoul could support collaboration between South Korean NGOs and internationally-recognized institutions to deliver similar projects, encouraging partnerships for the purpose of using best practices. Successful models can be supported to expand projects into other rural regions. In this regard, South Korean civilian experts and Korean diaspora can also be activated.

Experts have noted the financial feasibility of rehabilitating North Korea's rural energy sector through international assistance. ${ }^{53)}$ As part of the trustbuilding process, in the initial stages small-scale renewable energy projects that can have an immediate impact on the rural population's quality of life should be a key focus. From various standpoints - i.e., global trends ${ }^{54}$; South Korea's technological knowhow and NGOs' past experience; North Korea's electricity transmission problems, environmental conditions, interest, familiarity with the technology, and situation in rural regions; and the parameters of meeting people's needs through project longevity, participation, multiplication factor, and maximizing impact while minimizing diversion ${ }^{55}$ wind power for electricity generation and solar-heat projects for producing heat energy stand out as appropriate renewables to start with. ${ }^{56)}$

52) See Jerome Sauvage, "Small Wind Energy Project Improves Livelihoods in Rural Areas," United Nations (24 September 2012), available at <http://kp.one.un.org/energy-indprk/>; "N. Korea Wind Turbine Project by UNDP to Be Completed by 2013," (Yonhap News) North Korea Newsletter No. 231 (11 October 2012), available at $<$ http://english.yonhapnews.co.kr>.

53) James H. Williams, David Von Hippel, and Nautilus Team, "Fuel and Famine: Rural Energy Crisis in the DPRK," Asian Perspective 26-1 (Spring 2001), pp. 132-137.

54) Pilita Clark, "Renewables: A Rising Power," Financial Times (8 August 2013), available at <http://www.ft.com/cms/s/0/a41d86b4-ff9c-11e2-a244-00144feab7de.html\#axzz2n FunJ $3 \times S>$.

55) Proposed areas of project selection based on one man's 20 years of experience delivering humanitarian assistance to the DPRK. Erich Weingartner, "What Works Best?" CanKor (27 July 2013).

56) Considering North Korea's situation and South Korea's technology, the most suitable area for cooperation in renewables is likely wind and solar power. For technical details, see Hwa-Young Sin et al., "South Korean Citizens' Preferences on Renewable Energy Support and Cooperation Policy for North Korea," Renewable and Sustainable Energy Reviews 14 (2010), pp. 1383-1384. 


\section{Conclusion}

Trust is a gamble on one future contingency. Building trust requires a longterm effort - as its multidimensional nature would suggest. It involves many things including working with respect, having good communication, foregoing the blame game, moving forward with noble intentions, and getting beyond one's own self-interest. In the words of one man who for the past sixteen years has led his nonprofit organization's programs in the DPRK to foster community-level partnerships to develop self-sufficiency in health, education, and income, benefiting over one million people annually, "in order to break the cycle of mistrust, systemic to the context in the DPRK, like in any partnership, you have to demonstrate trust to get trust. This is the maxim we employ along with 'trust but verify'. This has worked for everybody, including our donors." ${ }^{\text {57) }}$

This study is fundamentally prescriptive, based on a humanitarian concern and an understanding that there exists a critical need for policy innovation to move the inter-Korean reconciliation process forward at a time when the relationship between Seoul and Pyongyang seems intractably Gordian. At this juncture in time, for the two Koreas, trust building could best be started if the leaderships on both sides recognize each country's system differences, embrace the principle of starting small, and accept a people-centered approach that seeks to create the weak ties between citizens on both sides that can lead to relationships where thin interpersonal trust can emerge. Considering Pyongyang's insecurities yet encouraging direction with its energy policy, both Chairman Kim Jong Un's statements about and President Park Geun-hye's emphasis on improving the quality of life of the North Korean people, and NGOs' past engagement with the DPRK in the provision of energy development assistance, targeting North Korean communities for renewable energy development cooperation could prove to be an effective and positive first small step in what can only be a long-term trust-building process.

Of course, focusing on renewables and empowering NGOs for this task

57) Robert E. Springs, remarks at the international conference on Capacity Building and Knowledge Sharing with North Korea: Past Successes and Future Prospects, Seoul, Korea, 12 June 2013. 
does have its shortcomings. For one, mutual lack of trust had hindered the international NGO-DPRK relationship in the past. ${ }^{58}$ Some past South Korean NGOs' participation involved incentives merely to promote organizational interests. ${ }^{59)}$ "Event" level engagement also may not spill over to other areas of cooperation, such as political and military, and therefore not lead to any immediate or fundamental change in the regime in Pyongyang. ${ }^{60)}$ In addition, negotiating for access to engage more rural regions will be a difficult task requiring much effort — but effort that must be made if we are to reach larger numbers of local people. Finally, as experts have mentioned, any kind of cooperative energy support programs coming from South Korea will need to be conducted in the spirit of true cooperation and on humanitarian level, and have a strategic plan to guarantee success and sustainability. ${ }^{61)}$

In this regard, the positive past experience of nongovernmental aid providers with local North Korean officials should not be overlooked as a means to build interaction and relationships between the peoples of the two Koreas that can lead to the building of thin interpersonal trust. This recommendation also does allow for complementary approaches, helps address humanitarian concerns, attempts to activate larger numbers of donors and reach larger numbers of beneficiaries, falls in line with local needs and the North Korean government's directions with its energy policy, and can establish people-to-people linkages between ordinary South and North Koreans that is likely to have lasting impact, working slowly to change mutual negative perceptions, which is the only way to begin to build mutual trust between the two societies that will advance inter-Korean reconciliation.

58) Matthew McGrath, "North Korea's Famine: A UN Representative Looks Back," NKNews.org (29 April 2013), available at <http://www.nknews.org>.

59) EunJeong Soh, "South Korean Civil Society and the Politics of Aid to North Korea," Journal of Peace and Unification 3-1 (Spring 2013), p. 102.

60) Kihl-jae Ryoo, "Prospects of the Leadership Structure of North Korea in the Post-Kim Jong-il Era," Korea and World Affairs 34-1 (Spring 2010), pp. 34-35.

61) Hwa-Young Sin et al., op. cit., pp. 1381-1382. 


\section{REFERENCES}

“Another Version of Confrontation Policy.” Pyongyang Times. 25 May 2013.

"Carbon Trade Arouses Interest." Pyongyang Times. 19 November 2011, p. 4.

Central Intelligence Agency (CIA). The World Factbook. Available at $<$ http://www.cia.gov/library/publications/the-world-factbook> (Accessed on 10 September 2012).

Choseonjungangnyeongam [North Korea Yearbook]. Pyongyang: Choseonjungangtongsinsa, 2011.

Chung, Oknim. "The Role of South Korean NGOs: The Political Context." In L. Gordon Flake and Scott Snyder. eds. Paved with Good Intentions: The NGO Experience in North Korea. Westport, Connecticut: Praeger, 2003, pp. 81-110.

Clark, Pilita. "Renewables: A Rising Power." Financial Times. 8 August 2013. Available at <http://www.ft.com/cms/s/0/a41d86b4-ff9c-11e2a244-00144feab7de.html\#axzz2nFunJ3xS >.

"Cornerstone of Korean Reunification." Pyongyang Times. 1 June 2013.

"Despite War Threats, N. Korean Border Units Hit by Growing AWOLs." Vantage Point 36-4. April 2013, p. 60.

"Full Text of Park's Inauguration Speech.” Yonhap News. 25 February 2013. Available at <http://english.yonhapnews.co.kr/national/2013/02/25/95/ 0301000000AEN20130225001500315F.HTML>.

Greacean, Chris and Nautilus Team. "Rural Re-electrification in the DPRK." Asian Perspective 26-1. Spring 2002, pp. 57-76.

Grzelczyk, Virginie. "Uncovering North Korea's Energy Security Dilemma: Past Policies, Present Choices, Future Opportunities." Central European Journal of International and Security Studies (CEJISS) 6-1. January 2012, pp. 132-154.

Haggard, Stephan and Marcus Noland. Witness to Transformation: Refugee Insights into North Korea. Washington, DC: Peterson Institute for International Economics, 2011.

Hayes, Peter and David F. von Hippel. "DPRK 'Collapse' Pathways: Implications for the Energy Sector and for Strategies Redevelopment/ Support." NAPSNet Special Report. 18 January 2011. Available at $<$ http://www.nautilus.org $>$.

Hayes, Peter, David von Hippel, and Scott Bruce. "The DPRK Energy Sector: Current Status and Future Engagement." Korean Journal of Defense Analysis 23-2. June 2011, pp. 161-165. 
Hayes, Peter, David von Hippel, Jungmin Kang, Tatsujiro Suzuki, Richard Tanter, and Scott Bruce. "Grid-locked." Bulletin of the Atomic Scientists 62-1. January/February 2006.

Hoffmann, Aaron M. "A Conceptualization of Trust in International Relations." European Journal of International Relations 8-3. 2002, pp. 375-401.

Hsu, Victor W. C. "Getting Acquainted with North Korea: A Journey of Gradual Discovery." 38 North. Washington, D.C.: U.S.-Korea Institute at SAIS, Johns Hopkins University. 1 April 2010. Available at $<\mathrm{http}: / /$ www.38north.org/?p=225>.

"It's Time to Reset Relations." Pyongyang Times. 8 June 2013.

Jenkins, Kevin. "North Korea: Waiting and Working in the DPRK." World Vision International. 12 September 2011. Available at $<$ http://www.wvi.org>. . "North Korea: The Old People Danced all Night." World Vision International. 4 October 2011. Available at $<$ http://www.wvi.org $>$.

"Key to Peace and Reunification of Korea." Pyongyang Times. 17 August 2013.

Khodyakov, Dmitry. "Trust as a Process: A Three-Dimensional Approach." Sociology 41-1. 2007, pp. 115-132.

Kim, Byeong-no. "Talbukja myeonjeobjosareul tonghae bon bukhansahoiui byeonhwa, 2008-2011" [Social Changes in North Korea, 2008-2011: Based on North Korean Refugees Survey]. Hyeondaebukhanyeongu [North Korean Studies Review] 15-1. April 2012, pp. 39-84.

Kim, Jong Un. "Let Us Brilliantly Accomplish the Revolutionary Cause of Juche, Holding Kim Jong Il in High Esteem as the Eternal General Secretary of Our Party - Talk to Senior Officials of the Central Committee of the Workers' Party of Korea, April 6, Juche 101 (2012)." Pyongyang: Foreign Languages Publishing House, 2012.

. "Let Us March Forward Dynamically Towards Final Victory, Holding Higher the Banner of Songun-Speech Delivered at the Military Parade Held in Celebration of the Birth of the Generalissimo Kim Il Sung, April 15 Juche 101 (2012).” Pyongyang: Foreign Languages Publishing House, 2012.

Kim, Min Gi. "Moves Toward Change Under the Kim Jong-Un Regime." Vantage Point 35-8. August 2012, p. 24.

Kim, Soo Am, Kook Shin Kim, Young Yoon Kim, Soon Hee Lim, EunMee Jeong, and Young Ja Park. The Quality of Life of North Korean: Current Status and Understanding. Seoul: KINU, December 2012.

"Knowledge Transfer and Training in a Difficult Climate-Cooperation with 
North Korea in the Areas of Climate Change and Green Development." Hanns Seidel Foundation. Available at <http://www.hss.or.kr/A1250 English.html> (Accessed on 21 September 2012).

Ko, Dong-hoon. "Capacity Building and North Korea: Pyongyang University of Science and Technology." Paper presented at the international conference on Capacity Building and Knowledge Sharing with North Korea: Past Successes and Future Prospects. Seoul, Korea. 12 June 2013.

"Korean Youths Devote Themselves to National Defense, Building of Thriving Nation.” KCNA. 26 August 2013.

Lankov, Andrei. "North Korea's 'Organizational Life' in Decline." Asia Times. 22 May 2012.

"Law on Consolidating Position of Nuclear Weapons State Adopted." KCNA. 1 April 2013.

"Law on Renewable Energy Enacted in DPRK." KCNA. 2 September 2013.

Mayer, Roger C., James H. Davis, and F. David Schoorman. "An Integrative Model of Organizational Trust." Academy of Management Review 203. 1995, pp. 709-734.

McGrath, Matthew. "North Korea's Famine: A UN Representative Looks Back." NKNews.org. 29 April 2013. Available at <http://www.nknews.org>.

"Military Capabilities Guarantee Sovereignty to Existence: Rodong Sinmun." KCNA. 30 May 2012.

Ministry of Unification. "Trust-Building Process on the Korean Peninsula." 23 September 2013. Available at $<$ http://eng.unikorea.go.kr $>$.

"N. Korea Wind Turbine Project by UNDP to Be Completed by 2013." (Yonhap News) North Korea Newsletter No. 231. 11 October 2012. Available at $<$ http://english.yonhapnews.co.kr>.

"North Korea also Turning to Renewable Energy Sources." Asahi Shimbun. 29 November 2011. Available at <http://ajw.asahi.com/article/asia/ korean_peninsula/AJ201111290057>.

“North Korea’s \$850 million Rocket Failure.” CNN.com. 13 April 2012.

"North Korean Economy Suffers in the New Year: Power Shortages and Prices on the Rise." NK Brief No. 11-01-26. Institute for Far Eastern Studies. 26 January 2011. Available at <http://ifes.kyungnam.ac.kr/ eng/FRM/FRM_0101V.aspx?code=FRM1012_000408>.

"Nuclear Energy Development Widely Sought." Pyongyang Times. 19 November 2011, p. 7.

“Our Party Line of Economic Construction and Nuclear Weapons Development 
Is Permanent." Rodong Sinmun. 3 May 2013 (in Korean).

Park, Geun-hye. "Trustpolitik and the Making of a New Korea." 15 November

2012. Available at <http://www.piie.com/blogs/nk/?p=8088> (Accessed on 23 March 2013).

Reed, Edward P. "From Charity to Partnership: South Korean NGO Engagement with North Korea." In Sung Chull Kim and David C. Kang. eds. Engagement with North Korea: A Viable Alternative. Albany, New York: SUNY Press, 2009, pp. 199-223.

Reed, Richard. "Relief Managers from Portland-based Mercy Corps Say U.S.

Let North Koreans Starve as Retribution for Missile Launch." The Oregonian. 13 April 2013.

"Renewable Energy in the DPRK." NCNK Newsletter 2-1. 13 January 2009.

Ri, Jong Chol. Songun Politics in Korea. Pyongyang: Foreign Languages Publishing House, 2012.

Ryoo, Kihl-jae. "Prospects of the Leadership Structure of North Korea in the Post-Kim Jong-il Era.” Korea and World Affairs 34-1. Spring 2010, pp. 24-37.

Sauvage, Jerome. "Small Wind Energy Project Improves Livelihoods in Rural Areas." 24 September 2012. Available at <http://kp.one.un.org/ energy-in-dprk/>.

Sin, Hwa-Young, Eunnyeong Heo, Sul-Ki Yi, and Jinhyo Kim. "South Korean Citizen's Preferences on Renewable Energy Support and Cooperation Policy for North Korea." Renewable and Sustainable Energy Reviews 14. 2010, pp. 1379-1389.

“Sinister Intent." Pyongyang Times. 1 June 2013.

Soh, EunJeong. "South Korean Civil Society and the Politics of Aid to North Korea.” Journal of Peace and Unification 3-1. Spring 2013, pp. 77-108.

"Special Report, FAO/WFP Crop and Food Security Assessment Mission to the Democratic People's Republic of Korea." 12 November 2012. Available at <http://www.fao.org/docrep/016/a1994e/a1994e00.pdf>.

Spoorenberg, Thomas and Daniel Schwekendiek. "Demographic Changes in North Korea: 1993-2008." Population and Development Review 38-1. March 2012, pp. 154-155.

Springs, Robert E. "Capacity Building and North Korea: The American Experience." Paper presented at the international conference on Capacity Building and Knowledge Sharing with North Korea: Past Successes and Future Prospects. Seoul, Korea. 12 June 2013.

Suh, Dae-Sook. "Military First Politics of Kim Jong Il." Asian Perspective 
26-3. Fall 2002, pp. 145-167

Swiss Agency for Development and Cooperation (SDC). "Catching Up on Capacity in DPR Korea - Partnership Results." Asia Brief. January 2011.

Von Hippel, David, Scott Bruce, and Peter Hayes. "Transforming the DPRK Through Energy Sector Development." 38 North. Special Report 11-3. Washington, D.C.: U.S.-Korea Institute at SAIS, Johns Hopkins University. 4 March 2011. Available at <http://www.38north.org>.

Weingartner, Erich. "What Works Best?" CanKor. 27 July 2013. Available at $<$ https://vtncankor.wordpress.com> (Accessed on 1 August 2013).

Williams, James H., David Von Hippel, and Nautilus Team. "Fuel and Famine: Rural Energy Crisis in the DPRK." Asian Perspective 26-1. Spring 2001, pp. 132-137.

Yi, Sul-Ki, Haw-Young Sin, and Eunnyeong Heo. "Selecting Sustainable Renewable Energy Source for Energy Assistance to North Korea." Renewable and Sustainable Energy Reviews 15. 2011, pp. 554-563.

"Youths at Forefront of Building Thriving Nation." Pyongyang Times. 27 August 2011, p. 5

[Received September 11, 2013; Revised November 25, 2013; Accepted November 28, 2013] 